\title{
THE ROLE OF FINANCIAL DEVELOPMENT, EDUCATION AND ECONOMIC GROWTH ON ENVIRONMENTAL QUALITY IN CAMEROON
}

\author{
DOI: 10.17261/Pressacademia.2020.1299 \\ JBEF- V.9-ISS.3-2020(4)-p.232-244
}

\author{
Aboubakary Nulambeh Ndzembanteh ${ }^{1}$, Kadir Yasin Eryiğit ${ }^{2}$ \\ ${ }^{1}$ Uludag University, Department of Economics, 16059, Nilüfer, Bursa, Turkey. \\ ndzembanteh10@yahoo.com, ORCID: 0000-0002-4039-6690 \\ ${ }^{2}$ Uludag University, Department of Economics, 16059, Nilüfer, Bursa, Turkey.
} kyeryigit@gmail.com , ORCID: 0000-0001-6857-7402

Date Received: April 24, 2020

Date Accepted: September 4, 2020

To cite this document

Ndzembanteh, A. N., Eryigit, K.Y., (2020). The role of financial developments, education and economic growth on environmental quality in Cameron. Journal of Business, Economics and Finance (JBEF), V.9(3), p.232-244.

Permanent link to this document: $\mathrm{http}: / /$ doi.org/10.17261/Pressacademia.2020.1299

Copyright: Published by PressAcademia and limited licensed re-use rights only.

\begin{abstract}
Purpose - The using of economic growth as an instrument to alleviate poverty in developing countries remains a challenge, as economic growth often emerges with greenhouse gases. In this regard, this study aimed to examine the impact of education, financial development, and economic growth on environmental quality in Cameroon.

Methodology - This study employs the Autoregressive Distributive Lag (ARDL) and the Toda-Yamamoto causality test methods to examine the relationship between the above-mentioned variables and carbon dioxide emissions in Cameroon's for the period 1980-2016.

Findings- From the ARDL bounds tests, we found that a long-run relationship exists between the variables and the Toda-Yamamoto causality tests reveal multiple unidirectional causalities, from carbon dioxide to financial development, economic growth, and foreign direct investment and from economic growth to human capital. Similarly, bidirectional causality runs between human capital and energy consumption, between human capital and financial development and lastly, between financial development and foreign direct investment.

Conclusion- It is therefore crucial for the government to develop policies that mitigate the spread of pollution and to encourage the practice of green education and sustainable finance in Cameroon.
\end{abstract}

Keywords: Cameroon, human capital, economic growth, financial development, environmental quality. JEL Codes: Q51, Q53, O44

\section{INTRODUCTION}

Nowadays, developing countries are becoming exposed to the danger of climate change and global warming. This is partly because human activities (farming, mining, deforestation, and industrialization) are inflicting permanent damage to the environment. In most developing countries, including that of Cameroon, the government has as objective to raise growth to reduce poverty, create jobs, improve the human capital development and to generate a friendly environment. However, it is quite perplexing to use economic growth as a policy objective since there is always a trade-off between this construct and environmental degradations. Economic growth often generates both positive and negative externalities on the environment. Positively, it goes along with an increase in consumption, rise in investment, reduction in poverty, high employment and the knowledge spillover from advanced societies to less advanced ones. Meanwhile negatively, it leads to the exploitation of natural resources and the emission of greenhouse gases that are harmful to the environment (Galeotti, 2007). Moreover, most third world countries are characterized with inadequate human capital, poor financial market and high dependency on primary activities (agriculture, forestry, mining, and fishing) see (The World Bank Report, 2009). Meanwhile, these sectors are quite vulnerable to environmental hazards, making it difficult to tackle the dual issues of climate change and poverty alleviation. Furthermore, the "pollution havens hypothesis", argues that jurisdictions with weak environmental regulations (developing countries) turn to attract more polluting industries from stronger nations (developed countries). This phenomenon is frequent in Sub Saharan African countries since the 
environmental policies to tackle the spread of greenhouse gases are limited. According to (Oxfam, 2020), the annual emissions of pollution (CO2) per head are 0.40 tons in Cameroon, 0.09 tons in Rwanda, 0.19 tons in Malawi, 0.49 tons in Nigeria, 8.9 tons in South Africa, 1.68 tons in India and 4.7 tons in Britain. From this research, someone in Britain will take just five days to emit the same amount of $\mathrm{CO} 2$ that someone in Rwanda, in a year. Nevertheless, in recent years, numerous efforts have been made by the governments in developing countries to promote financial development, human capital development, economic growth, and environmental sustainability. However, the ability of education, financial development and economic growth to impact environmental quality in developing countries has been a subject of hot debate and remains inconclusive. While several scholars are of the view that education, financial development and economic growth have a positive effect on environmental quality (Awad and Warsame, 2017) and (Hundie, 2018), other researchers have demonstrated that these variables are negatively related with environmental quality (Ali, 2018) and (Phuong et al., 2018).

Because the relationship between these variables are inconclusive and considering the fact that economic growth often generate more greenhouse gases (GHG), particularly carbon dioxide emission, it is therefore, crucial to examine the environment educationnexus and environment growth-nexus in developing countries. The environment growth-nexus is usually model using the environmental Kuznets curve (EKC). This curve was first introduced to examine the relationship between income inequality and per capita income (Kuznets, 1955) and later used by Grossman and Krueger (1995) and Selden and Song (1994) to study the relationship between economic growth and environmental pollution.

The major research questions of this study are: does education, financial development, and economic growth influence environmental conditions? The main objective of this study is to determine the relationships between education, financial development, economic growth and environmental quality in Cameroon. This will be done by using the ARDL bounds test and the Toda-Yamamoto causality test methods. Unlike other studies, the structural breaks in the series have been considered, using the Lee and Strazicich (2003) test methods. The rest of the paper is structured as follows. The first section is the introductory remarks and the next section covers the literature reviews. The last section is the estimation techniques, the findings, and the conclusion.

\section{LITERATURE REVIEW}

In this section focus on the theoretical studies that examine the relationship between human capital, financial development, economic growth, foreign direct investment, energy consumption and environmental quality.

\subsection{Theoritical Literature}

In literature, most studies have focused on the relationship between between growth/income, energy consumption, foreign direct investment and environmental quality (carbon dioxide emissions). The theory used to explain this relationship has three strands. The first one centres on the carbon dioxide emissions, energy consumption, and economic growth nexus. This part mostly focuses on the Environmental Kuznets Curve hypothesis. Kuznets (1955) established the hypothesis, which studied the inverse relationship between income inequality and economic growth. This was later redeveloped by (Grossman and Krueger, 1991), to study the relationship between economic growth and environmental quality, known as the Environmental Kuznets Curve (EKC).

The EKC hypothesis postulates that in the initial stage of economic development, an increase in national income is accompanied by an increase in environmental pollution. After that, a stage is reached in the developmental process of a country after which an increase in national income is not complemented with an increase in environmental pollution. The reason being that, in the early stage of development, nations do not usually care for the quality of the environment, as more utilization of natural resources are essential in building-up a nation. However, once a certain level of income is riched, nations try to care about the quality of their environment, since certain environmental issues generate health problems. In other word, an inversed U-shaped association, exists between economic growth and environmental pollution.

The second strand is about the association between energy consumption and economic growth. In literature, researchers have proposed four hypothesis to test this relationship. The first is the neutrality hypothesis, states that there is no causal relationship between energy consumption and economic growth. In others word, countries energy policies have no impact on economic growth. Secondly, the growth hypothesis, that assumes a unilateral causality, run from energy consumption to economic growth. This implies that any increase in the consumption of energy will lead to economic growth. Thirdly, the conservation hypothesis, which settled that a unilateral causality is moving from economic growth to energy consumption. Lastly, the feedback hypothesis, which concludes that, there is a bilateral causality between energy consumption and economic growth. 
The third strand focus on the relationship between foregn trade and environmental pollution. There are two important hypothesis that study this relationship, the Pollution Halo Hypothesis $(\mathrm{PHH})$ and the Pollution Haven Hypothesis. According to the pollution havens hypothesis, environmental regulations will move polluting activities to poorer countries. As environmental consciousness raises globally, countries settle down to improve new environmental regulations, with severe sanctions (Harrison, 1997). The Pollution halo effect on the other hand, states that foreign direct investment leads to the improvement of environmental quality in developing countries, as it goes along with the transfer of skills, technology, capital and better management techniques. In other words, multi-national enterprises have the tendency to transfer clean energy and technology to developing countries that further reduce the level of carbon dioxide emissions. Meanwhile, in recent period, researchers have introduced other variables like financial development and foreign direct investment into the analysis as control variables. Meanwhile, the studies that examine the relationship between human capital and environmental quality are limited in literature. This study will therefore add to the above, by looking at the impact of education on environmental quality.

The impact of education on environmental quality may take place in various forms. Firstly, educated people tend to be more environmental friendly, by demanding for more environmental improvement. Secondly, educated people have better access to information which at times induce them to potentially consume more environmental friendly products. On the other hands, human capital accumulation (Education) could be detrimental to the environment in the sense that it could generate high productivities and consumptions that may in turn raises pollution. Likewise, high education may lead to high income meanwhile the high income raises consumption that further create more environmental damages. In countries with high literacy rates, the purchasing power of individuals are generally high and people have the ideology of "consume more to be happier" making them to develop the desire to live well without taking care of their environment. Nevertheless, the focus of this paper is to jointly examine the impact of financial development, human capital and economic growth on environmental quality.

The theory of financial development was first introduced by McKinnon and Shaw. This theory holds that financial sector development is quite essential for a nation's growth. It states that the forces of demand and supply operating in the market turn to generate an equilibrium rate of interest that in turn lead to high savings and investment. The financial sectors are vital in modern market economies. It acts as an engine of growth in facilitating payment and the provision of intermediary services between the lenders and borrowers. These sectors equally offer households, and firms with good management tools (Beck, 2013).

Financial development affects economic growth in different channels and researchers have grouped them into two broad categories (Levine, 2005). The first view is based on the standard neoclassical framework and is regarded as a direct channel. According to this view, financial development will stimulate growth through an increase in domestic investment and saving thereby reducing the cost of capital. The second view focuses on indirect channels and according to this interpretation, financial development provides the catalyst for certain collateral benefits like domestic institutional development, better governance, macroeconomic discipline that positively spillover to economic growth.

Sehrawat, Giri and Mohapatra (2015) state that economic growth is driven by changes in the number of factors of production (such as labor and capital) or increases in the efficiency by which the factors are used. Hence, if international financial integration could lead to the growth of the factor of production or efficiency gains in the use of such factors, then it would promote economic growth. Likewise, economic efficiency depends on free markets for goods, labor and finance, and a minimal state. Levine (2005) states that financial development is a good predictor of future economic growth, capital accumulation, and technological change. Even though some theories suggest that the development of the financial markets has an insignificant effect on the real sector, there is a positive, first-order relationship between financial development and economic growth.

\subsection{Empirical Literature}

This section gives a brief survey on several studies to determine whether education, financial development, economic growth, foreign direct investment and energy consumption are important drivers of environmental quality in Cameroon.

\subsubsection{Education and Environmental Quality}

Human capital accumulation is determined through the learning ability of individual and it saves as the engine for economic growth. Chakraborty and Gupta (2014) examined the relationship between human capital, environmental quality and economic growth and find that environmental quality and human capital are positively related. The authors state that educated people turn to use the available resources efficiently without causing much harms to the environment. On the contrary, environmental pollution turns to yield a negative effect on the health of an individual, which goes a long way to lower the learning ability of that individual. Likewise, pollution may impact human capital negatively particularly when noise pollution turns to disturb the learning 
environment. Meanwhile Roth (2017) states that air pollution turn to harm the scholastic achievement and human capital formation.

Goetz et al., (2016) investigate the relationship between human capital, income and environmental quality and find that higher educational attainment has an independent, positive effect on the quality of the environment. In other words, countries with high literacy rate turn to have better environmental conditions. This implies that education plays a leading role not just in generating growth but also in bringing additional benefit in the improvement of the environment. Torras and Boyce (1998) regress environmental pollution on income, literacy rate, Gini coefficient of income inequality and find that literacy rate has a significant negative effect on pollution particularly in low income countries, while Petrosillo et al., (2007) find that tourists attitudes are highly dependent on their education level. In other words, those with high school attainments turn to generate less environmental damages. Hower, in some instance, human capital (education) turn to have a detrimental effect on the quality of the environment, especially in countries that have passed through economic transformation (agriculture to industry) and from less polluting human capital to more polluting physical capital. In these type of countries, environmental pollution will take the form of a U-shape.

\subsubsection{Financial Development and Environmental Quality}

Moghadam and Lotfalipour (2015) investigate the effect of financial development on environmental quality in Iran using the method of Auto Regression Model Distributed Lag (ARDL) with data that runs from 1970 to 2011. The findings show that financial development causes lots of damages to the Iranian environment meanwhile trade openness turns to reduce these damages. Alam et al., (2016) examines the impact of financial development in Pakistan using the quarterly data that runs from 1985 to 2004 . The author concludes similar results and further argues that financial development acts as an impediment to the environment.

On the other hand, Li et al., (2015) jointly study the relationships between financial development, environmental quality and economic growth in 102 countries, using the generalized method of moments (GMM) estimation methods for the period 1980 to 2010. Their results show that financial development positively affects environmental quality. Saud, Chen, Saud et al., (2019) recently examine the impact of financial development and economic growth on environmental quality for a panel of 59 Belt and Road Initiative (BRI) countries, throughout 1980 to 2016. The authors conclude that financial development positively enhanced environmental quality in BRI countries.

\subsubsection{Economic Growth, Energy Consumption and Environmental Quality}

N. Agarwal (2012) analyzes the joint impact of economic growth, foreign direct investment (FDI) and financial development on environmental quality in Malaysia, using time series data that runs from the period1980 to 2008. The study finds that the environment-growth nexus via the Environment Kuznets Curve Hypothesis (EKCH) is positive in Malaysia. Aboagye (2015) investigates the impact of environmental qualities on economic growth in SSA, using panel data within the period 1985 to 2010. The author confirms the existence of the Environmental Kuznets Curve (EKC) for energy consumption but not for CO2 emissions. This finding indicates that in the long run, pollution emissions are instead increasing in Malaysia.

Hilaire and Kaffo Fotio (2014) examine the impact of economic growth on environmental quality for four Congo Basin countries (Cameroon, Congo, Gabon and the Democratic Republic of Congo) within the period 1978 to 2012. The author demonstrates that in the long run, economic growth has a positive impact on $\mathrm{CO} 2$ emissions in these countries. Likewise, Phimphanthavong (2013) investigates the relationship between economic growth and environmental degradation using time series analysis between 1980 to 2010. While using the EKC's hypothesis, he confirms that in the early stage, economic growth increases pollution that turns to fall after reaching a high level of income.

Awad and Warsame (2017) examine the impact of economic growth on carbon emissions in 54 African countries with data ranging from 1990 to 2014. The authors use the method of panel data analysis to verify the presence of the environmental Kuznets curve (EKC) hypothesis but came out with contradictory results. However, Bond et al. (2015), using time series data shows that economic growth is detrimental to the environment in the long run and the authors thus confirm the relevance of the EKC in that country. Carillo and Maietta (2014) employ the method of dynamic panel data to verify the impact of growth on environmental quality in Italy. The authors strongly confirm the existence of the EKC hypothesis in that country. Meanwhile, Fakher and Abedi (2017) recently analyzed the relationship between economic growth, foreign direct investment and environmental quality in some selected developing countries using panel data that runs from 1983 to 2013 . The authors settle that in the long run, economic growth has a positive impact on environmental quality.

Aali-Bujari et al., (2017) investigate the impact of energy used on economic growth in the Organization for Economic Cooperation and Development (OECD) countries during the period 1977 to 2014, using the panel data analysis. It was found that energy 
consumption is positively related to economic growth in the long. Mugableh (2013) investigates the effects of economic growth and energy consumption on CO2 emissions in Malaysia for the period 1971 to 2012 by using the ARDL method. The results indicate the existence of co-integrating relationships among the variables. The author also finds that energy consumptions have a positive impact on economic growth and CO2 emissions in the short and long-run. Meanwhile, Saidi and Hammami (2015) employ the dynamic panel data to investigate the impacts of carbon dioxide emission and economic growth on energy consumptions and finds a result, that is contradicting the EKC hypothesis.

Hundie (2018) analyses the relationship between energy consumption, affluence, financial development, trade openness, urbanization, population and CO2 emissions in Ethiopia by employing the time series data that runs from 1970 to 2014 . In using the ARDL bound tests, the author concludes that energy consumption, population, trade openness and economic growth have a positive impact on $\mathrm{CO} 2$ in the long-run. On the other hand, Ali (2018) examines the variables that generate carbon emissions in France with a specific focus on foreign direct investment (FDI), financial development, economic growth, energy consumption and energy research innovations using the annual data that runs from 1955 to 2016 . The author demonstrates that energy research has a negative impact, on carbon emissions in France while senergy consumption is positively linked to carbon emissions.

\subsubsection{Economic Growth, Energy Consumption and Environmental Quality}

loannis Kostakis (2011) investigates the role of foreign direct investment (FDI) inflows on environmental quality (C02) for the period 1970 to 2010 in Asian countries, using the ARDL, FMOLS and OLS methods. The author finds that FDI inflows do not generate a negative impact on the Singaporean and other Asian countries in the short run but does in the long run. Meanwhile, Abdouli and Hammami (2017) investigate the impact of foreign direct investment inflows, environmental quality, and capital stock on economic growth in 17 the Middle East and North African Countries (MENA) countries. Using panel analysis, that runs from 19902012, the authors find a similar result, where FDI positively impact environmental quality in the long run. Phuong et al., (2018) investigate the causal relationship between $\mathrm{CO} 2$ emissions, FDI and economic growth in Vietnam using annual time series data that runs for the period 1986 to 2015. The authors find that there exists a long-run relationship between the aforesaid variables in Vietnam.

To sum up, the relationship between human capital, financial development, economic growth, foreign direct investment, energy consumption and carbon dioxide emissions remains ambiguous. The using of different method, sample of country/countries and the time period, could alter the results. This study differs from other studies in that it considers the multiple structural breaks in the Cameroon's time series and the introduction of the various diagnostic tests, as explained in the methodology part. In this regard, it will contribute to the relevant literature.

\section{DATA AND METHODOLOGY}

We hypothesize that environmental quality is determined by education, financial development, economic growth, foreign direct investment, and energy consumption, based on Brock and Taylor (2010). The data are collected from various sources. The data on carbon dioxide emissions, economic growth, financial development, education and energy consumption are collected from the World Development Indicators meanwhile that of foreign direct investment is extracted from the United Nation Statistics Division (UNSD). The studyl employs the Cameroon time series annual data that runs from 1980 to 2016. The justification of the time frame is based on the availability of data and various events that has taken place in Cameroon.

The emission of carbon dioxide per capita is measured in metric tons per capita and is estimated from the combustion of fossil energies and cement industries in liquid, solid, or gas form and is considered in this study as an indicator of environmental quality. Education corresponds to secondary school enrollment often used as an indicator of human capital and it is measured in percentages meanwhile for financial development, researchers often employed numerous variables as a proxy in literature. In this regard, Munir et al. (2013) stated that the variables commonly use as proxy for financial development are foreign direct investment, deposit rate, lending rate, and broad money (M2). In this respect, we have considered credit to the private sector as an indicator of financial development and is measured in percentage of GDP. For economic growth, it is captured using GDP, measured in constant 2010 USD. Foreign direct investment and energy consumption are considered in this study as control variables like in most studies in literature. Besides, foreign direct investment is measured as a percentage of GDP and is used to capture the effects of pollution havens hypothesis in Cameroon, while energy consumption is measured in kg of energy. The model is specified as,

$$
\mathrm{CO}_{\mathrm{t}}=\mathrm{f}\left(\mathrm{FDI}_{\mathrm{t}}, \mathrm{FD}_{\mathrm{t}}, H C_{\mathrm{t}}, G D P_{\mathrm{t}} E N_{\mathrm{t}}\right)
$$

By taking the log of both side, we then obtained equation two as noted below; 


$$
L C O 2_{t}=\alpha_{0}+\beta_{1} L F D I_{t}+\beta_{2} L F D_{t}+\beta_{3} L H C_{t}+\beta_{4} L G D P_{t}+\beta_{5} L E N_{t}+\varepsilon_{t}
$$

Where $\mathrm{LCO}_{t}$ in equation 2 represents the log of Carbon dioxide emission, $L F D I_{t}$ stands for the log of foreign direct investment and $L F D_{t}$ indicates the log of financial development. Likewise, $L G D P_{t}$ measures the log of economic growth, $L H C_{t}$ pinpoints the log of human capital (education), $L E C_{t}$ signifies the log of energy consumption. $\alpha_{0}$ is a constant term while $\varepsilon_{t}$ is the white noise term and subscript $t$ is the time period. Moreover, $\beta_{i}(i=1,2,3,4,5)$ are the estimated parameters and are projected to be positive.

\section{ESTIMATION METHODS}

Because Cameroon is a developing economy, that at times experience internal and external shocks, we will, therefore, employ the structural break unit-roots test to study the integrating properties of the variables recommended by Clemente et al. (1998). These structural breaks either take the form of additive outliers (IO model) or double-break additive outliers (AI model) see Hundie (2018). The structural breaks usually used the dummy variables and are presented as shown below;

$$
\begin{aligned}
& y_{t}=\mu+\delta_{1} D U_{1 t}+\delta_{2} D U_{2 t}+\bar{y}_{t} \\
& \bar{y}_{t}=\sum_{i=1}^{k} \omega_{1 i} D T_{b 1, t-i}+\sum_{i=1}^{k} \omega_{2 i} D T_{b 2, t-i}+\alpha \bar{y}_{t-i}+\sum_{i=1}^{k} \theta_{i} \Delta \bar{y}_{t-i}+e_{t} \\
& y_{t}=\mu+\delta_{1} D U_{1 t}+\delta_{2} D U_{2 t}+\varphi_{1} D T_{b 1, t}+\varphi_{2} D T_{b 2, t}+\alpha y_{t-i}+\sum_{i=1}^{k} \theta \Delta y_{t-i}+e_{t}
\end{aligned}
$$

Equation 4, indicates two structural breaks models, in which $D U_{m t}=$ for $t>T_{b m}+1$ and 0 otherwise, for $m=1,2 . T_{b 1}$ and $T_{b 2}$ are the two breakpoints. Baum et al. (1999) as cited in Hundie (2018) argue that $\bar{y}_{t}$ should represents the residuals of the estimation that stands for the dependent variable as shown in equation 5 above.

The co-integrating properties of the variables are examined by applying the recent Author Regressive Distributive Lag (ARDL) method. This approach is suitable compares to the Johansen (1988) and Johansen and Juselius (1990) tests of co-integration. Particularly, this method turns to minimize the endogeneity problems, the stationarity problems, and is quiet applicable irrespective of whether the model is I (0) or I (1) see Hundie (2018). The ARDL model with the error-correction term is given as;

$$
\begin{aligned}
\Delta C O 2_{t}= & \alpha_{1}+\sum_{i=1}^{p} \beta_{1 i} \Delta C O 2_{t-i}+\sum_{i=0}^{q_{1}} \eta_{1 i} \Delta F D I_{t-1}+\sum_{i=0}^{q_{2}} \gamma_{1 i} \Delta F D_{t-1}+\sum_{i=0}^{q_{3}} \theta_{1 i} \Delta H C_{t-1}+\sum_{i=0}^{q_{4}} \pi_{1 i} \Delta G D P_{t-1}+\sum_{i=0}^{q_{5}} \phi_{1 i} \Delta E C_{t-1} \\
& +\delta_{1} L C O 2_{t-i}+\delta_{2} L F D I_{t-i}+\delta_{3} L F D_{t-i}+\delta_{4} L G D P_{t-i}+\delta_{5} L E C_{t-i}+\varepsilon_{1 t} \\
E C T_{t}= & C O 2_{t}-\alpha_{2}-\sum_{i=1}^{p} \beta_{2 i} C O 2_{t-i}-\sum_{i=0}^{q_{1}} \eta_{1 i} \Delta F D I_{t-1}+\sum_{i=0}^{q_{2}} \gamma_{1 i} \Delta F D_{t-1}+\sum_{i=0}^{q_{3}} \theta_{1 i} \Delta H C_{t-1}+\sum_{i=0}^{q_{4}} \pi_{1 i} \Delta G D P_{t-1}+ \\
& \sum_{i=0}^{q_{5}} \phi_{1 i} \Delta E C_{t-1}
\end{aligned}
$$

The parameters that show the corresponding long-run multipliers are given by $\delta_{i}$, where $I=1,2,3,4,5$. Meanwhile, the short run coefficients of the ARDL model are represented with $\beta_{i}, \eta_{i}, \gamma_{i}, \theta_{i}, \pi_{i}$ and $\phi_{i}$. In the ARDL bounds testing approach, we have two stages. The first stage is to investigate whether a long-run relationship exist between the variables in equation 7 . In this regard, an appropriate lag length is selected, based on the Schwartz Bayesian Criteria (SBC). The bounds testing procedure is based on the joint F-statistics or Wald statistics that examine the null hypothesis of no co-integration, $H_{o}: \delta_{i}=0$ against the alternative hypothesis of $H_{1}: \delta_{i} \neq 0, \mathrm{I}=1,2,3,4,5$.

In case the calculated F-statistic is above the upper band level, the null hypothesis is rejected, indicating the presence of cointegration. On the other hand, if it falls below the critical bound, the null hypothesis of no co-integration is not rejected and finally, but if it lies between the critical bounds then the result is inconclusive. The second stage is to estimate the long-run model, represented by equation 8 .

\section{EMPIRICAL RESULTS}

The plot of Cameroon's annual data is presented in Figure 1 with two breakpoints. It is shown that the dates of these structural breaks in most cases point to: (a) Lake Nyos disaster and the petroleum crisis between 1985 to 1993 period, (b) the 1994 to 2004 local currency devaluation and the post-electoral crisis; and (c) the 2008 to 2009 financial crisis that affected many countries in the world, including Cameroon. 
Figure 1: Plot of Cameroon's Actual Data with Two Breakpoints
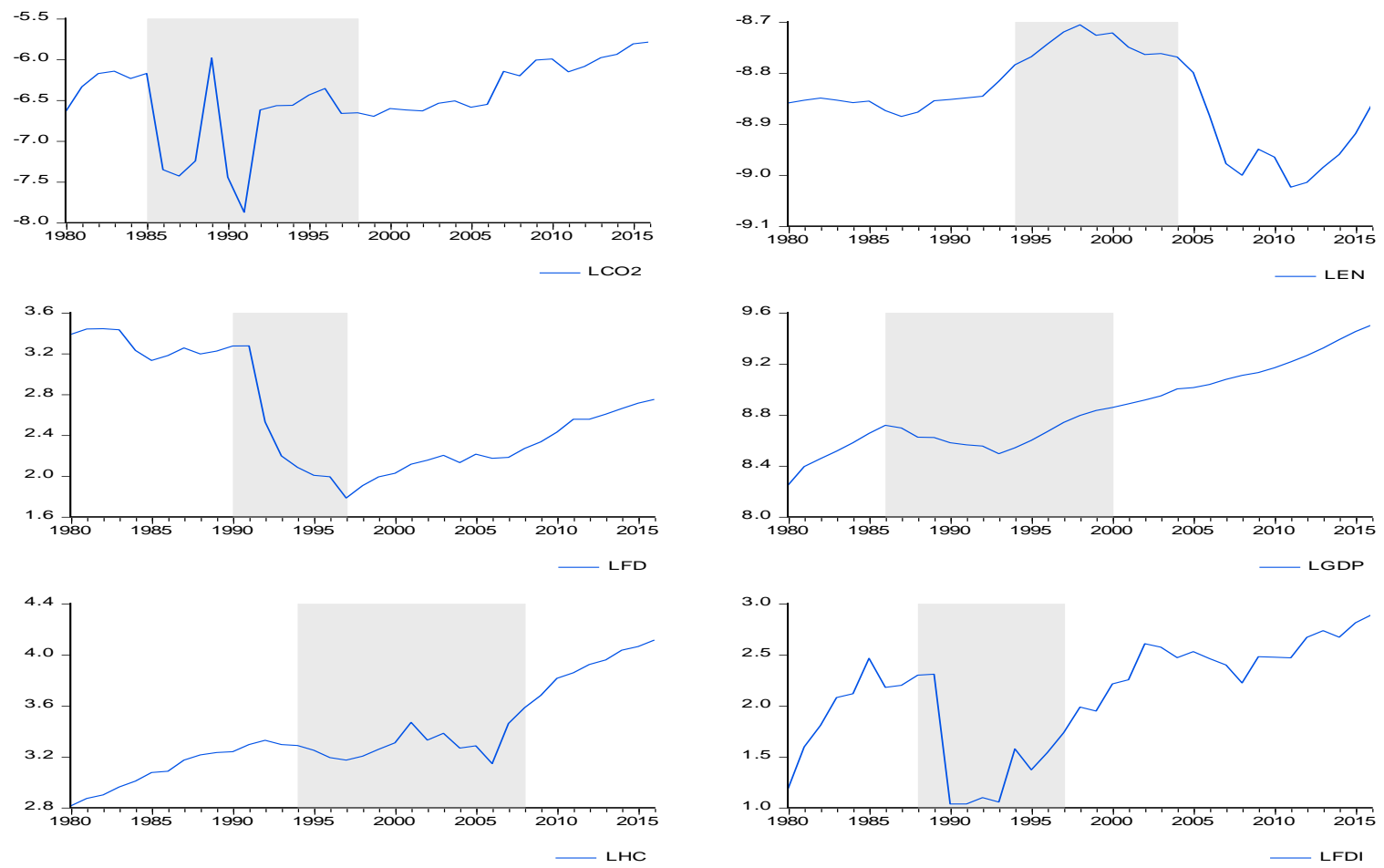

The variables, model types, and the two structural breaks unit roots tests are depicted as shown in Table 1 below. According to Lee and Strazicich (2003), all the variables are stationary at a 5 percent significance level, and thus suitable to conduct the ARDL bounds tests .

Table 1: Lee and Strazicich (2003) Unit Root Tests

\begin{tabular}{|c|c|c|c|c|c|c|}
\hline Series & Model & $\operatorname{Lag}$ & Break times & $\lambda$ & $t$-statistics & Critical values 5\% \\
\hline $\operatorname{LCO}_{t}$ & Model C & 1 & $\begin{array}{l}1986 \\
1998\end{array}$ & $\begin{array}{l}0.2 \\
0.6\end{array}$ & -6.27 & -5.74 \\
\hline$L F D I_{t}$ & Model C & 3 & $\begin{array}{l}1988 \\
1997\end{array}$ & $\begin{array}{l}0.2 \\
0.6\end{array}$ & -5.84 & -5.74 \\
\hline$L F D_{t}$ & Model C & 3 & $\begin{array}{l}1990 \\
1997\end{array}$ & $\begin{array}{l}0.2 \\
0.6\end{array}$ & -7.55 & -5.74 \\
\hline$L G D P_{t}$ & Model C & 3 & $\begin{array}{l}1986 \\
2000\end{array}$ & $\begin{array}{l}0.2 \\
0.6\end{array}$ & -5.45 & -5.74 \\
\hline
\end{tabular}




$\begin{array}{llllllr}\boldsymbol{L H C}_{\boldsymbol{t}} & \text { Model C } & 2 & 1994 & 0.4 & -5.10 & -5.65 \\ & & 2008 & 0.6 & & \\ & & & & & \\ \boldsymbol{L E C}_{\boldsymbol{t}} & \text { Model C } & 4 & 1994 & 0.4 & -4.95 & -5.67\end{array}$

Note: $p$ - values at the $5 \%$ significance level were obtained from Lee and Strazicich (2003).

Before conducting the ARDL bounds tests, the lag structure is first selected with the help of the Akaike Information Criterion (AIC). The lag orders $(3,3,2,3,3,3)$ are chosen, with critical values I $(0)=2.62$ and I $(1)=3.79$, significant at $5 \%$ level. From the analysis, we found that the calculated F-statistics is 11.41 , and comparing it with the critical values, the null hypothesis is rejected, showing that there exists a long-run relationship between the variables.

Next, the estimation of the long-run coefficients of the $\operatorname{ARDL}(3,3,2,3,3,3)$ model, is conducted and presented in Table 2 . The results demonstrate that there exists a long-run relationship between the variables. It is deduced from the results that financial development and human capital are the variables that significantly impact carbon dioxide emissions (in the long run. Specifically, a $1 \%$ increase in foreign direct investment and financial development will raise carbon dioxide emissions by $0.01 \%$ and $1.34 \%$ respectively. Whereas, a $1 \%$ increase in economic growth, human capital and energy consumption will reduce carbon dioxide emissions by about $1.09 \%, 3.71 \%$ and $0.99 \%$ correspondingly.

Table 2: Long-Run Model Estimates

\begin{tabular}{lcr}
\hline Regressors & Coefficients & t-values \\
\hline$L F D I_{t}$ & 0.011 & 0.980 \\
$L F D_{t}$ & 1.342 & $0.034^{* *}$ \\
$L G D P_{t}$ & -1.090 & 0.396 \\
$L H C_{t}$ & -3.713 & $0.051^{* *}$ \\
$L E C_{t}$ & -0.989 & 0.411 \\
$D T_{1}$ & 0.162 & $0.012^{* *}$ \\
$D T_{2}$ & 0.008 & 0.583 \\
Diagnostic tests & Test-statistics & $\mathbf{p}$-value \\
\hline Heteroscedasticity (ARCH) & 0.698 & 0.687 \\
Normality test & 0.221 & 0.895 \\
Serial correlation LM & 3.343 & 0.088 \\
\hline *and & &
\end{tabular}

*and ${ }^{* *}$ indicate significant at $1 \%$ and $5^{*}$ level.

Furthermore, the results of the short-run model are presented in Table 3. These results suggest that foreign direct investment and economic growth are statistically significant in impacting carbon dioxide emissions in the short-run, meanwhile, financial development, human capital and energy consumptions do not. We equally note that economic growth and energy consumption are variables that dominate in augmenting carbon dioxide emissions in the short-run. The diagnostic tests demonstrate that this model is free from heteroscedasticity, normality, and serial correlation problems. Additionally, the coefficient of the error correction term, ECT (-1) is negative (-94.8\%) and statistically significant at $5 \%$ level. This shows that about $95 \%$ of any deviation of carbon dioxide emissions in the short-run will be adjusted in the long-run and thus, support the existence of a long-run relationship between the variables. 
Table 3: Short-Run Model Estimates

*and** indicate significant at $1 \%$ and $5 \%$ level

\begin{tabular}{lrr}
\hline Regressors & Coefficient & t-values \\
\hline$\Delta L E C_{t}(-1)$ & 5.874 & $2.555^{* *}$ \\
$\Delta L F D_{t}$ & 0.494 & 0.878 \\
$\Delta L F D_{t}(-\mathbf{1})$ & -0.032 & $-2.777^{* *}$ \\
$\Delta L F D I_{t}$ & 0.706 & $2.574^{* *}$ \\
$\Delta L G D P_{t}$ & 9.901 & $4.960^{*}$ \\
$\Delta L H C_{t}$ & -0.139 & 0.253 \\
$\Delta L H C_{t}(-\mathbf{2})$ & 1.234 & $2.136^{* *}$ \\
$\Delta L D T_{1}$ & 0.153 & $7.690^{*}$ \\
$\Delta L D T_{2}$ & 0.007 & 0.574 \\
ECT(-1) & -0.948 & $-3.014^{* *}$ \\
\hline
\end{tabular}

The following outcomes have been noted. Firtsly, education has a negative impact on carbon dioxide emissions in Cameroon and is in line with those of Goetz et al., (2016) and Roth ( 2017). This finding is supported with the fact that educated people often have good access to information, that makes them more environmentally friendly. Nonetheless, in some situations, people with a high level of education may adversely influence the environment through the output growth. For instance, a high accumulation of human capital through education could raise investment, consumption, economic growth, and carbon dioxide emission. Focusing on financial development, we note that it has a positive impact on carbon dioxide emission, which supports the previous work of Moghadam and Lotfalipour (2015). Meanwhile, Li et al., (2015) and Saud et al., (2019) settled for a negative relationship between financial development and carbon dioxide emission.

Moreover, a negative relationship was established between economic growth and carbon dioxide emission, which indicates that pollution turn to fall when economic growth increases. This result is in line with the works of Bond et al., ( 2015), Valadez and Hu (2016) and Ali (2018) but contradicts the previous findings by Fakher and Abedi (2017) and Hundie ( 2018). It was equally shown that foreign direct investment is positive but statistically insignificant to impact carbon dioxide emission in the long run. The positive links between foreign direct investment and carbon dioxide emission, thus support the relevance of the pollution havens hypothesis in Cameroon. This is partially because foreign firms turn to rip the developing countries from their natural resources by producing goods that are harmful to the quality of the environment (Libanda et al., 2017). This outcome is in line with that of Abdouli and Hammami (2017) but invalidates the work of of Joysri (2009).

The causal effects between financial development, foreign direct investment, economic growth, human capital, energy consumption and environmental quality is tested, using the Tada-Yamamoto (TY) causality test method. The results as shown in Table 4, indicate that, unidirectional causality runs from carbon dioxide to human capital, economic growth and foreign direct investment at $95 \%$ confidence interval.

We also find other unidirectional causalities, running from economic growth to human capital and from human capital to foreign direct investment. Meanwhile, bidirectional causalities flow between human capital and energy consumption, between human capital and financial development and finally, between financial development and foreign direct investment. Interestingly, the TY causality result also confirmed that financial development and energy consumption do not cause carbon dioxide emission in the short run. In the theoretical literature part of this study, we mentioned three nexus between human capital, financial development, economic growth, foreign direct investment, energy consumption and environmental quality. Based on the hypothesized theory, this finding, support the neutrality hypothesis in Cameroon, where no causal effect runs between energy consumption and economic growth. 
Table 4: Toda-Yamamoto Causality Tests

\begin{tabular}{lllllll}
\hline $\begin{array}{l}\text { Dependent } \\
\text { Variables }\end{array}$ & $L C O 2_{t}$ & $L E C_{t}$ & $L F D_{t}$ & $L F D I_{t}$ & $L G D P_{t}$ & $L H C_{t}$ \\
\hline$L C O 2_{t}$ & -- & {$[2.366]$} & {$[5.430]$} & {$[10.966]$} & {$[27.133]$} & {$[9.262]$} \\
& & $(0.500)$ & $(0.143)$ & $(0.012)^{* *}$ & $(0.000)^{*}$ & $(0.026)^{* *}$ \\
$L E C_{t}$ & {$[0.884]$} & -- & {$[4.023]$} & {$[1.655]$} & {$[0.801]$} & {$[8.191]$} \\
& $(0.830)$ & & $(0.259)$ & $(0.647)$ & $(0.849)$ & $(0.042)^{* *}$ \\
$L F D_{t}$ & {$[0.868]$} & {$[1.709]$} & -- & {$[8.601]$} & {$[0.471]$} & {$[8.840]$} \\
& $(0.829)$ & $(0.635)$ & & $(0.035)^{* *}$ & $(0.925)$ & $(0.032)^{* *}$ \\
$L F D I_{t}$ & {$[0.769]$} & {$[0.901]$} & {$[18.636]$} & -- & {$[0.214]$} & {$[7.009]$} \\
& $(0.857)$ & $(0.825)$ & $(0.000)^{*}$ & & $(0.975)$ & $(0.072)$ \\
$L G D P_{t}$ & {$[2.855]$} & {$[0.581]$} & {$[1.854]$} & {$[17.756]$} & -- & {$[7.610]$} \\
& $(0.415)$ & $(0.901)$ & $(0.603)$ & $(0.001)^{*}$ & & $(0.055)^{* *}$ \\
$L H C_{t}$ & {$[0.752]$} & {$[7.774]$} & {$[7.909]$} & {$[7.637]$} & {$[1.666]$} & --
\end{tabular}

*and ${ }^{* *}$ indicate significant at $1 \%$ and $5 \%$ level and the value in [ ] and ( ) represent Chi sq. statistics and $p$-values.

Finally, the stability of the model is checked by applying the CUSUM and the CUSUM of square tests as shown in Figures 2 and 3 below. Both tests pinpoint that the estimated coefficients are stable at a $5 \%$ level of significance. From these results, it is concluded that this model is stable and may not lead to a biased estimate.

Figure 2: CUSUM at $5 \%$ significance

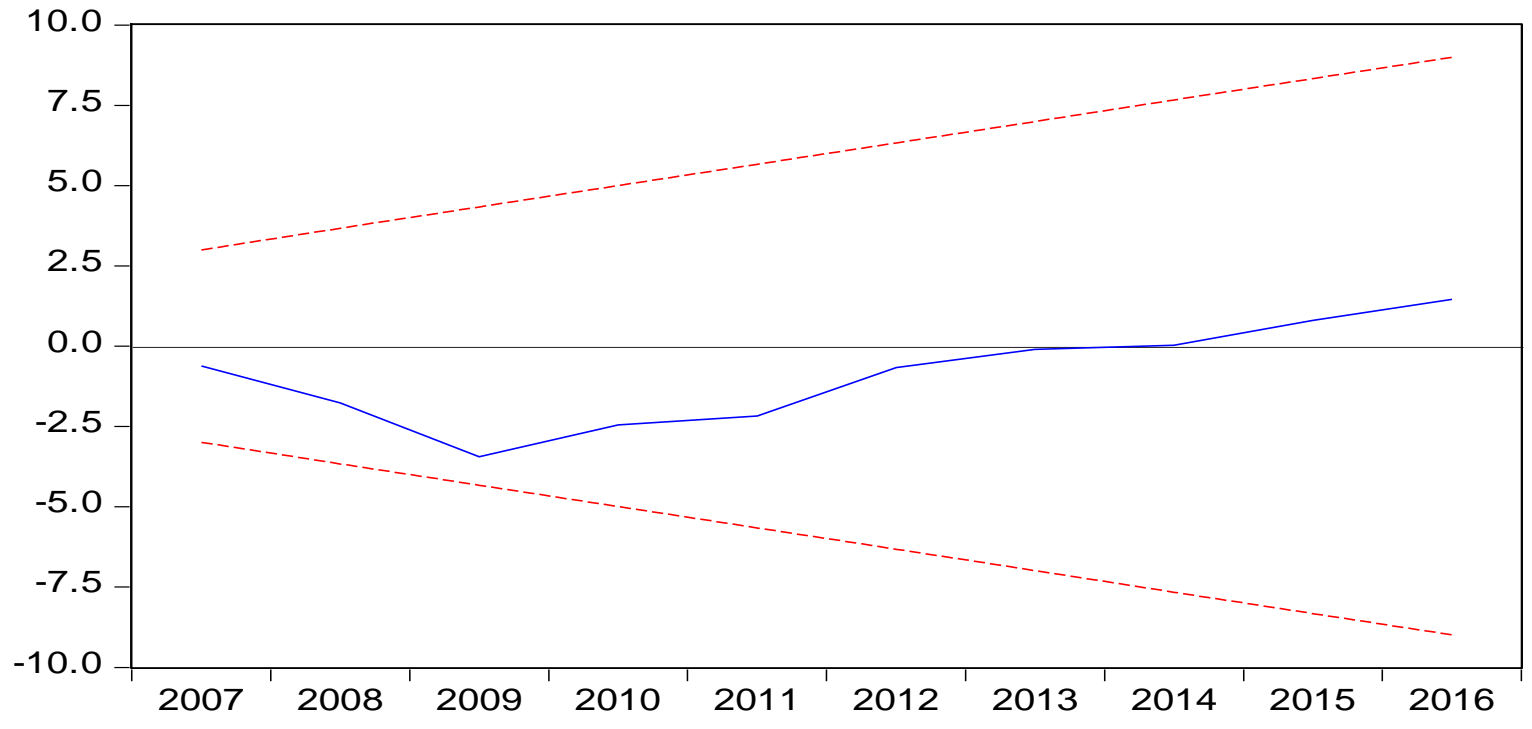


Figure 3: CUSUM of Squares at $5 \%$ Significance

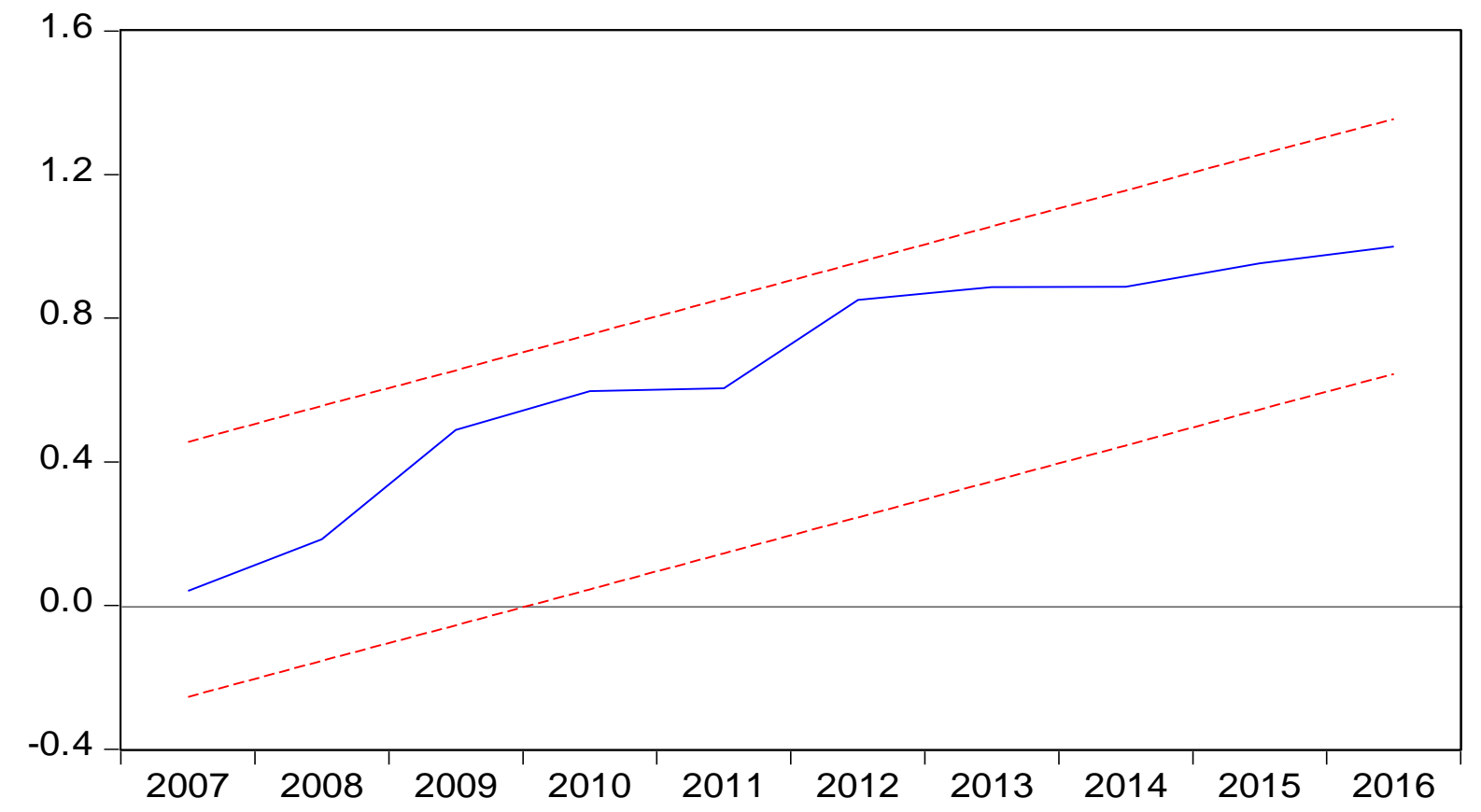

\section{CONCLUSION}

This study aims to investigate the factors affecting environmental quality in Cameroon. The ARDL bounds tests reveal that the calculated F-statistics is more than the critical values, indicating the presence of a long-run relationship among the variables. We also found that the ECT (-1) is negative (-94.8\%) and statistically significant at $5 \%$ level. This shows that about $95 \%$ of deviation in the previous year will be adjusted in the long-run. Specifically, a $1 \%$ increase in $L F D I_{t}$ and $L F D_{t}$ will raise $L C O 2_{t}$ by $0.01 \%$ and $1.34 \%$ respectively. Meanwhile, a $1 \%$ increase in $L G D P_{t}$ and $L H C_{t}$ reduce $L C O 2_{t}$ by close to $1.09 \%$ and $3.71 \%$ respectively. From these results, it is deduced that human capital $\left(L H C_{t}\right)$ is an important variable that contributes in improving the quality of the environment. As a recommendation, the government should develop measures that raise the level of human capital. Also, a more technical system of education couple with high enrollment of women in higher education should be encouraged. Moreover, a negative association is settled between economic growth and carbon dioxide emissions. This negative relationship between these two constructs indicates that, pollution turn to decrease when income increases and thus support the relevant of environmental Kuznets curve (EKC) in Cameroon. It is therefore crucial for the government to implement growth and eco-friendly policies that mitigate the spread of pollution. Above all, we found that financial development is significant and positively related to carbon dioxide emissions. This implies that financial development acts as a stimulus in raising environmental pollution in Cameroon. It is therefore mandatory for policy-makers to develop strategies that mitigate the spread of pollution by encouraging the practice of green and sustainable finance. Moreover, the government should develop the financial systems in a way that promotes inclusive finance among the younger generations and women in particular. Finally, a positive long-run relationship is found between foreign direct investment and carbon dioxide emissions, indicating that the pollution havens hypothesis is relevant in Cameroon. It is therefore recommended that the government should develop policies that attract environmentally friendly products to Cameroon.

\section{REFERENCES}

Aali-Bujari, A., Venegas-Martínez, F., \& Palafox-Roca, A. O. (2017). Impact of Energy Consumption on Economic Growth in Major Organization for Economic Cooperation and Development Economies (1977-2014): A Panel Data Approach. International Journal of Energy Economics and Policy, $7(72), 18-25$.

Abdouli, M., \& Hammami, S. (2017). The Impact of FDI Inflows and Environmental Quality on Economic Growth: an Empirical Study for the MENA 
Countries. Journal of the Knowledge Economy, 8(1), 254-278.

Aboagye, S. (2015). Towards Economic Growth and Development in Sub-Saharan Africa: Does That Mar the Environment? The Department of Economics, University of Ghana, Accra, 1-17.

Alam, M. S. and S. J. H. S. and N. A. and S. (2016). Financial development and environmental quality: The way forward. In MPRA Working Paper (Issue 46733).

Ali, M. (2018). Environmental Degradation in France : The Effects of FDI , Financial Development, and Energy Innovations. In MPRA Working Paper (Issue 26 July).

Awad, A., \& Warsame, M. H. (2017). Climate Changes in Africa : Does Economic Growth Matter ? A Semi-parametric Approach. International Journal of Energy Economics and Policy, 7(1), 1-8.

Beck, T. (2013). Finance for development : A research agenda. In Development Dilemmas (Issue September, pp. 4-27).

Bond, C. A., Burger, N., Nguyen, P., \& Justice, R. (2015). Implications of Australian Economic Growth for Environmental Sustainability.

Brock, W. A., \& Taylor, M. S. (2010). The Green Solow model. Journal of Economic Growth, 15(2), 127-153.

Carillo, F., \& Maietta, O. W. (2014). The Relationship between Economic Growth and Environmental Quality : The contributions of economic structure and agricultural policies. New Medit N., 13(1), 15-21.

Chakraborty, B., \& Gupta, M. R. (2014). Human Capital Accumulation, Environmental Quality, Taxation and Endogenous Growth. In Economic Research Unit, Indian Statistical Institute. (pp. 193-215).

Fakher, H., \& Abedi, Z. (2017). Relationship between Environmental Quality and Economic Growth in Developing Countries ( based on Environmental Performance Index ). Environmental Energy and Economic Research, 1(3), 299-310.

Galeotti, M. (2007). Economic growth and the quality of the environment: Taking stock. Environment, Development and Sustainability, 9(4), 427454.

Goetz, S. J., Debertin, D. L., \& Pagoulatos, A. (2016). Human Capital, Income, and Environmental Quality: A State-Level Analysis. Agricultural and Resource Economics Review, 27(02), 200-208.

Grossman G.M. and A.B. Krueger (1995), Economic growth and the environment, The Quarterly Journal of Economics $110,353-377$.

Harrison, G. S. E. and A. E. (1997). Moving to Greener Pastures? Multinationals and the Pollution Haven Hypothesis 1(January), 1-18.

Hilaire, N., \& Kaffo Fotio, H. (2014). Effects of Economic Growth on CO2 Emissions in the "Congo Basin" Countries. International Journal of Economics and Finance, 7(1), 107-117.

Hundie, S. K. (2018). Modelling Energy Consumption, Carbon Dioxide Emissions and Economic Growth Nexus in Ethiopia: Evidence from Cointegration and Causality Analysis. Turkish Journal of Agriculture - Food Science and Technology Available, 6(6), 699-709.

Ioannis Kostakis, S. L. and E. S. (2011). Foreign Direct Investment and Environmental Degradation: Further evidence from Brazil and Singapore. In MPRA Working Paper (Issue 46733).

Jesus Clemente, Antonio Montanes, M. R. (1998). Testing for a unit root in variables with a double change in the mean. Economics Letters 59(October), 175-182.

Johansen, S. (1988). Statistical Analisis of Cointegration Vectors. Journal Of Economic Dynamics and Control, 12(September), $231-254$.

Joysri, A. (2009). Fdi , Growth and the Environment : Evidence From India on Co2 Emission During the Last Two Decades. Journal of Economic Development, 34(1), 43-58.

Kuznets, S. (1955). Economic Growth and Income Inequality. The American Economic Review, 45(1).

Lee, J., \& Strazicich, M. C. (2003). Minimum Lagrange Multiple Unit Root Test With Two Structural Breaks. Review of Economics and Statistics, 85(4), 1082-1089.

Levine, R. (1997). Financial development and economic growth: views and agenda. Journal of Economic Literature, XXXV(June), 688-726.

Levine, R. (2005). Chapter 12 Finance and Growth: Theory and Evidence. In Handbook of Economic Growth (Vol. 1, Issue SUPPL. PART A, pp. 865934).

Li, S., Zhang, J., \& Ma, Y. (2015). Financial development, environmental quality and economic growth. Sustainability (Switzerland), 7(7), 93959416.

Libanda, J., Marshall, D., \& Nyasa, L. (2017). The Effect of Foreign Direct Investment on Economic Growth of Developing Countries: The Case of 
Zambia. British Journal of Economics, Management \& Trade, 16(2), 1-15.

Moghadam, H. E., \& Lotfalipour, M. R. (2015). Impact of Financial Development on the Environmental Quality in Iran. Chinese Business Review, 13(09), 537-551.

Mugableh, M. I. (2013). Analysing the CO2 Emissions Function in Malaysia: Autoregressive Distributed Lag Approach. Procedia Economics and Finance, 5(13), 571-580.

Munir, S., Chaudhry, I. S., \& Akhtar, M. H. (2013). Financial Liberalization and Economic Growth in Pakistan: Empirical Evidence from Co-integration Analysis. In Pakistan Journal of Social Sciences 33(2), 227-241.

N. Agarwal, R. (2012). Economic Globalisation, Growth and the Environment: Testing of Environment Kuznet Curve Hypothesis for Malaysia. Journal of Business \& Financial Affairs, 01(02), 1-8.

Oxfam. (2020). Britons reach Africans' annual carbon emissions in just two weeks. https://www.theguardian.com/environment/2020

Petrosillo, I., Zurlini, G., Corlianò, M. E., Zaccarelli, N., \& Dadamo, M. (2007). Tourist perception of recreational environment and management in a marine protected area. Landscape and Urban Planning, 79(1), 29-37.

Phimphanthavong, H. (2013). The Impacts of Economic Growth on Environmental Conditions in Laos. Int.J.Buss.Mgt.Eco.Res., 4(5), 766-774.

Phuong, N. D., Thi, L., \& Tuyen, M. (2018). The Relationship between Foreign Direct Investment, Economic Growth and Environmental Pollution in Vietnam : An Autoregressive Distributed Lags Approach. International Journal of Energy Economics and Policy, 8(5), 138-145.

Roth, S. (2017). Air pollution, educational achievements, and human capital formation. In IZA World of Labor (Issue August).

Saidi, K., \& Hammami, S. (2015). The impact of CO2 emissions and economic growth on energy consumption in 58 countries. Energy Reports, 1, 62-70.

Saud, S., Chen, S., Danish, \& Haseeb, A. (2019). Impact of financial development and economic growth on environmental quality: an empirical analysis from Belt and Road Initiative (BRI) countries. Environmental Science and Pollution Research, 26(3), 2253-2269.

Sehrawat, M., Giri, A. K., \& Mohapatra, G. (2015). The impact of financial development, economic growth and energy consumption on environmental degradation: Evidence from India. Management of Environmental Quality: An International Journal, 26 (5), 666-682.

Selden T.M. and D.S. Song (1994), Environmental quality and development: is there a Kuznets curve for air pollution emissions?, Journal of Environmental Economics \& Management 27, 147-162.

Soren Johansen, K. J. (1990). Maximum liklihood Estimation and Inference on Cointegration-witth Applications to the Demand for money. Oxford Bulletin of Economics and Statistics, 52 (2), 0305-9049.

The World Bank Report. (2009). The World Bank Annual Report. In The World Bank Annual Report.

Torras, M., \& Boyce, J. K. (1998). Income, inequality, and pollution: A reassessment of the environmental Kuznets curve. Ecological Economics, 25(2), 147-160.

Valadez, G. V., \& Hu, J. (2016). Relationship between the Environment and Economic Growth in China via Exports : A Perspective of Ecological Impact ( 2000-2014). Journal of Environmental Protection, 7(2152-2219), 1670-1692. 